\title{
Comparison of the Static Balance, Strength and Flexibility Characteristics of the University Students Who Taken Artistic Gymnastic Lesson
} Ömer ÖZER ${ }^{1}$, Recep SOSLU ${ }^{1}$

\author{
${ }^{1}$ High school of Physical Education and Sports, Karamanoğlu Mehmetbey University, Karaman, Turkey \\ Address Correspondence to Ö, Özer e-mail: omerozer@kmu.edu.tr \\ * This research was presented as a poster at shape america national convention \& expo20-24 may 2018. \\ Abstract
}

The aim of this study is to examine the effects of a training program specific to Artistic Gymnastics branch on the performance of university students. 72 university student studying in the School of Physical Education and Sports were participated in the study voluntarily as a control and experiment group. The experimental group was given artistic gymnastics training program for 12 weeks, 2 days a week and 60 minutes. For the data obtained, the homogeneity of the normality variance was tested and then the mixed ANOVA analysis was used to determine the difference in the pretest and posttest. When the flamingo balance values were examined, a significant difference was found between the groups $(\mathrm{F}(1,71)=4.93, \eta 2=.07$, $\mathrm{p}<.05)$. A difference in post-test flexibility scores and pre-test scores $(\mathrm{F}(1,71)=7.81, \mathrm{\eta} 2=.10, \mathrm{p}<.05)$, a significant difference was found between the posttest scores and the pretest scores in strength values $(\mathrm{F}(1.34,95.46)=40.69, \mathrm{n} 2=.36, \mathrm{p}<.05)$. As a result, it is thought that the extra training done in gymnastics lesson increases the success of the lesson and it is thought that this type of training will increase the success level in all applied lessons, not only for the gymnastics class.

Keywords: Gymnastics, balance, flexibility, strength, plank.

\section{INTRODUCTION}

The human body is in physical, physiological, biomotoric and psycho-mental forms with a great balance (homeostasis) and adaptation $(8,25,28)$. Artistic Gymnastics (AC) requires a combination of flexibility, strength, speed, anaerobic endurance, coordination and anthropometric characteristics specific to the branch $(3,31)$. Artistic gymnastics has 6 different (parallel, ring, pull-up, handle horses, ground and jump table) tools for men and 4 (asymmetric parallel, balance, place and jump table) for a woman $(3,5,14)$. Gymnastics is a sports branch with specific competition rules consisting of periodic and compulsory movements on instruments standardized $(3,5)$.

According to Major (20), AC which is being in a complex sports branch requires a high level of biomotor properties. In order to perform $\mathrm{AC}$ techniques, a strong skeleton, nerve-muscle, force, connective tissue and appropriate flexibility should be provided (22). Each movement technique requires the coordination of different balance, strength and flexibility with each other (5). Even though it varies according to the instruments, it should be durable, suspended, jumping, rotating, and contains many movement groups (27). AC is taught to students in compulsory lessons in the departments of Physical Education and Sports in the departments of Physical Education and Sports, and in elective lessons in some universities (15). Students generally come from different sports branches but they are required to show and teach techniques specific to AC branch. The absence of any physical preparation of the students causes them to fail the techniques and cause them to be disabled (19).

When the literature is examined, there are not enough studies about the pre-qualification and lesson performance of the students taking AC lesson. The aim of this study is to investigate the effect of 12 weeks AC branch training program on AC lesson performance of university students.

\section{MATERIAL AND METHOD}

A total of 72 student volunteers participated in the study at the School of Physical Education and Sports. The participants were randomly divided into two groups: 36 (22 males and 14 females) and 36 (22 males and 14 females). The mean age of the experimental group was $20.49 \pm .99$ years, their height was $171 \pm \mathrm{cm}$ and their weight was $66.41 \pm \mathrm{kg}$. The mean of control group age was $22.36 \pm 1.15$ years, height was $172 \pm 8 \mathrm{~cm}$ and weight was $64.58 \pm 10.25 \mathrm{~kg}$. 


\section{Training program}

AC training program was applied to the experimental group for 2 weeks and 60 minutes for 12 weeks. 1-week adaptation training was applied prior to the start of the training for correcting their fails and mistakes.

Data collection tool

\begin{tabular}{lllll}
\hline Exercises & 1.set & 2.set & 3.set & 4.set \\
\hline Push up & $30 \mathrm{sec}$ & $30 \mathrm{sec}$ & $30 \mathrm{sec}$ & $30 \mathrm{sec}$ \\
\hline Sit up & $30 \mathrm{sec}$ & $30 \mathrm{sec}$ & $30 \mathrm{sec}$ & $30 \mathrm{sec}$ \\
\hline Squat & $30 \mathrm{sec}$ & $30 \mathrm{sec}$ & $30 \mathrm{sec}$ & $30 \mathrm{sec}$ \\
\hline Right leg Squat & $30 \mathrm{sec}$ & $30 \mathrm{sec}$ & $30 \mathrm{sec}$ & $30 \mathrm{sec}$ \\
\hline Left leg Squat & $30 \mathrm{sec}$ & $30 \mathrm{sec}$ & $30 \mathrm{sec}$ & $30 \mathrm{sec}$ \\
\hline
\end{tabular}

Flamingo Balance Test: The subjects stood on the beam which was $50 \mathrm{~cm}$ long, $5 \mathrm{~cm}$ height and 4 $\mathrm{cm}$ wide. While balancing on the preferred leg, the free leg was flexed at the knee and the foot of this leg held close to the buttocks. Then the instructor started the stopwatch and the subjects tried to stand in this position for one minute. The stopwatch was stopped each time the subjects lost the balance. It was started again until they lost the balance again. When the time was over, the subjects' attempts after they fell this score was recorded (29).

Sit and Reach test: Flexibility was measured using a sit-and-reach test, using a sit-and-reach box (height 32, length $35 \mathrm{~cm}$.). The subjects sat with their heels firmly against the testing box. Subjects kept their knees extended and placed their right hand over the left, with the long fingers even, and reached forward as far as they could by sliding their hands along the measuring board. A tape measure on top of the measuring board indicated in centimeters how far beyond the toes each individual reached. The score (in centimeters) is the greatest distance contacted by the fingertips past the toes. 3 trials were performed, and the average was used for data analysis $(4,21)$.

Plank test: The subjects were instructed to assume a position with the shoulders and elbows flexed at $90^{\circ}$ with only the forearms and toes in contact with the ground. The subjects had to maintain a straight, strong line from the head to the toes with an extended leg position, keeping the head and spine in a neutral position. The distance between the big toes was maintained at hip width to prevent inducing hip adduction force. With the start of the period, the time until the subject was exhausted and / or until he had disrupted his posture was recorded in seconds. Straight, right arm and left arm plank test was applied to the participants (26).

\section{Statistical Analysis}

SPSS 23 package program was used for statistical calculations of the obtained data. For the data obtained, the homogeneity of the normality variance was tested and then the mixed ANOVA analysis was used to determine the difference in the pretest and posttest.

\section{RESULT}

\begin{tabular}{|c|c|c|c|c|}
\hline Variables & Balance & $N$ & Pre-test & Post-test \\
\hline \multirow{3}{*}{$\begin{array}{l}\text { Experiment } \\
\text { group }\end{array}$} & Right & \multirow{3}{*}{36} & $6.05 \pm 3.5$ & \multirow{2}{*}{$3.22 \pm 3.07^{*}$} \\
\hline & Flamingo & & 2 & \\
\hline & $\begin{array}{c}\text { Left } \\
\text { Flamingo }\end{array}$ & & $\begin{array}{c}6.19 \pm 4.0 \\
0\end{array}$ & $4.05 \pm 3.48^{*}$ \\
\hline \multirow{2}{*}{ Control group } & $\begin{array}{c}\text { Right } \\
\text { Flamingo }\end{array}$ & \multirow[t]{2}{*}{36} & $\begin{array}{c}5.47 \pm 3.3 \\
8\end{array}$ & $6.36 \pm 3.74$ \\
\hline & $\begin{array}{c}\text { Left } \\
\text { Flamingo }\end{array}$ & & $\begin{array}{c}6.14 \pm 4.0 \\
5\end{array}$ & $8.44 \pm 5.33$ \\
\hline
\end{tabular}

When the flamingo balance values were examined, a significant difference was found between the groups $(\mathrm{F}(1,71)=4.93, \mathrm{\eta} 2=.07, \mathrm{p}<.05)$. There were statistically significant differences between post flamingo balance scores and control group flamingo balance scores.

Table 2. Flexibility Values of Participants

\begin{tabular}{cccc}
\hline Variables & $N$ & $\begin{array}{c}\text { Pre test } \\
(\mathrm{cm})\end{array}$ & $\begin{array}{c}\text { Post test } \\
(\mathrm{cm})\end{array}$ \\
\hline Experiment group & & $37.12 \pm 5.85$ & $39.69 \pm 6.17^{*}$ \\
\cline { 1 - 1 } \cline { 3 - 4 } Control group & 36 & $31.83 \pm 6.58$ & $30.91 \pm 6.87$ \\
\hline
\end{tabular}

Experimental group posttest elasticity scores were significantly different compared to pre-test scores $(\mathrm{F}(1,71)=7.81, \mathrm{\eta} 2=.10, \mathrm{p}<.05)$. In addition, experimental group posttest scores differed significantly from the control group posttest scores $(\mathrm{p}<.05)$. 
Table 3. Strength Values of Participants

\begin{tabular}{|c|c|c|c|c|}
\hline Variables & Strength & $N$ & $\begin{array}{l}\text { Pre-test } \\
(\mathrm{sec})\end{array}$ & $\begin{array}{c}\text { Post-test } \\
(\mathrm{sec})\end{array}$ \\
\hline \multirow{3}{*}{$\begin{array}{c}\text { Experiment } \\
\text { group }\end{array}$} & Plank & \multirow{3}{*}{36} & $137.76 \pm 99.96$ & $167.35 \pm 116.96^{*}$ \\
\hline & $\begin{array}{l}\text { Right } \\
\text { Plank }\end{array}$ & & $68.46 \pm 30.63$ & $83.62 \pm 26.85^{*}$ \\
\hline & $\begin{array}{l}\text { Left } \\
\text { Plank }\end{array}$ & & $67.86 \pm 31.17$ & $78.00 \pm 22.55^{*}$ \\
\hline \multirow{3}{*}{$\begin{array}{l}\text { Control } \\
\text { group }\end{array}$} & Plank & \multirow{3}{*}{36} & $130.05 \pm 92.80$ & $126.42 \pm 95.88$ \\
\hline & $\begin{array}{l}\text { Right } \\
\text { Plank }\end{array}$ & & $61.86 \pm 22.09$ & $57.94 \pm 15.85$ \\
\hline & $\begin{array}{l}\text { Left } \\
\text { Plank }\end{array}$ & & $61.39 \pm 20.30$ & $59.28 \pm 17.97$ \\
\hline
\end{tabular}

A significant difference was found between the experimental group of posttest scores and the pretest scores $(\mathrm{F}(1.34,95.46)=40.69, \mathrm{n} 2=.36, \mathrm{p}<.05)$. There was a statistically significant difference between the experimental and posttest strength scores of the experimental and control group $(\mathrm{F}(1$, $71)=3.38, \mathrm{\eta} 2=.05, \mathrm{p}>.05$ ).

Table 4. Lessons achievement point values of the participants

\begin{tabular}{cccc}
\hline Variables & $N$ & Midterms & Final \\
\hline $\begin{array}{c}\text { Experiment } \\
\text { group }\end{array}$ & & $55 \pm 12.30$ & $72.63 \pm 9.21^{*}$ \\
\hline Control group & & $43.42 \pm 10.61$ & $43.05 \pm 12.55$ \\
\hline
\end{tabular}

It is determined that the final test values of the experimental group have improved according to the pre-test values $(\mathrm{F}(1.70)=102.59, \mathrm{\eta} 2=.36, \mathrm{p}<.05)$. There were statistically significant differences between the experimental and post-test scores and the control group $(\mathrm{F}(1,70)=66.94, \mathrm{\eta} 2=.49, \mathrm{p}<.05)$.

\section{CONCLUSION AND EVALUATION}

Success in the implementation of the movements depends on the basic motoric features in AC $(2,9,10)$. According to Daly, the strength has a significant effect on the performance of the AC (10). Particularly in artistic gymnastics, the development of different types of force causes significant effects in the implementation of movements in ground, balance and jumping table tools (17). However, coordinating their movement requires a certain balance system $(30,32)$. The ability to balance is also an important factor in gaining skills such as walking, running and jumping (13).

There are many studies investigating the motoric components of gymnasts. Çoknaz et al. (9) in gymnastics of the different stretching exercises flexibility values, Savucu et al. (24) found a statistically significant difference in flexibility and strength parameters of the gymnastics-specific training program. Vandorpe et al. (31) 168 compared the strength and elasticity parameters of the gymnast and found a significant difference in strength and elasticity parameters. Delas et al. (11) found a statistically significant difference in the balance, flexibility and strength parameters of gymnasts. While Alpkaya (2), in his work, integrated gymnastics branch with the specific training program of 7-year-old gymnastics balance, flexibility and strength have provided improvements. Kesilmiş (18) determined that there is a statistically significant difference in balance and force parameters applied to a gymnastics training program for preschool children. Durukan et al. (13), in their study on the motor development of basic gymnastics training, found a statistically significant difference in both parameters after the strength and balance tests applied before and after basic gymnastics training. In Bayraktar, (13) study flexibility, balance, and shuttle tests were applied to 11-12 age group gymnastics, swimming and athletics and gymnastics flexibility, balance and shuttle parameters were better than swimmers and athletes. In the study of Demirel et al. (12), preschool students who took gymnastics training in summer school had an 8-week training program and found a statistically significant difference in balance and flexibility parameters. In our study, the strength, balance and flexible properties of basic motoric components are parallel to the literature. In particular, it is thought that strength exercise have an effect on balance and flexibility studies have positive effects on maintaining joint space angle.

When the literature is examined, there are not many studies examining the effect of basic motoric properties on gymnastics performance in schools. Agopyan (1) investigated the effect of 8-week training program on rhythmic gymnastics competition series on the competition. Before and after training, there were significant differences in the force parameters in the experimental group. Although, Berisha and Çilli (7) evaluated the force parameters of 90 male students in 15 and 16 age group who had taken gymnastics training in the 
school curriculum for 5 years and found that students with more successful values in the force tests had higher technical scores, In Atılgan et al (3) study, they found a statistically significant negative difference between the equilibrium instrument of the gymnasts and the balance tests performed by the laboratory. In our study, it was found that the test grade of the experimental group was higher than the midterm and the final average compared to the control group. İn addition that experiment group strength, flexibility and balance were affected in a positive way.

As a result, it can be said that the extra training done in the lesson of gymnastics increases the success of the lesson and not only for the gymnastics lesson but also for all the applied lessons.

\section{REFERENCES}

1. Agopyan A. Ritmik cimnastikte teknik antrenman yöntemlerinin performansla ilişkisi. T.C. Marmara Üniversitesi Sağlık Bilimleri Enstitüsü Beden Eğitimi Ve Spor Anabilim Dalı. Doktora Tezi. İSTANBUL,2000.

2. Alpkaya U. The effects of basic gymnastics training integrated with physical education lessons on selected motor performance variables Academic journals, Educational Research and Reviews, 8(7),2013. 317-321. doi: 10.5897/ERR12.250.

3. Atilgan AOE, Akin M, Alpkaya U, Pina, S. Investigating of relationship between balance parameters and balance lost of elite gymnastics on balance beam. International Journal of Human Sciences, 2012.9 (2), 1260-1271.

4. Bakırcı A, Kılınç F. Hazırlık Periyodunda Uygulanan Kombine Antrenmanların Üniversite Basketbol Takımının Performans Düzeyine Etkisi. İnönü Üniversitesi Beden Eğitimi Ve Spor Bilimleri Dergisi, 2014. 1(2), 48-67

5. Ballı ÖM. "Bruininks-Oseretsky Motor Yeterlik Testinin Geçerlik, Güvenirlik Çalışması ve Beş-Altı Yaş Grubu Çocuklara Uygulanan Jimnastik Eğitim Programının Motor Gelişime Etkisinin İncelenmesi" Ankara Üniversitesi Fen Bilimleri Enstitüsü Ev Ekonomisi(Çocuk Gelişimi Ve Eğitimi) Anabilim Dalı Doktora Tezi. ANKARA, 2009.

6. Bayraktar L. 11-12 yaş grubu yüzme, cimnastik ve atletizm sporları yapan bayan sporcuların fiziksel ve motorsal gelişim özelliklerinin karşılaştırılması.T.C. Marmara Üniversitesi Sağlık Bilimleri Enstitüsü Beden Eğitimi Ve Spor Anabilim Dalı Yüksek Lisans Tezi. İSTANBUL, 2005.

7. Berisha M, Çilli M. 15-16 Yaş Çocuklarda Temel Jimnastik Derslerinde Kazanılan Farklı Kuvvet Türlerinin Jimnastik Performansı Üzerine Etkilerinin İncelenmesi. CBÜ Beden Eğitimi ve Spor Bilimleri Dergisi, 2016. 11(1), 37-45.

8. Çakmakçi E, Tatlici A, Yirmibeş B. Comparıson Of Some Performance Parameters Of Physically Active Mentally Retarded And Inactive Mentally Retarded Individuals. European Journal of Physical Education and Sport Science. 2018.

9. Çoknaz H, Yıldırım NÜ, Özengin N. Artistik Cimnastikcilerde Farklı Germe Sürelerinin Performansa Etkisi. Spormetre Beden Eğitimi ve Spor Bilimleri Dergisi, 2008. 6(3), 151-157
10. Daly RM, Bas, SL, Finch CF. Balancing the risk of injurytogymnasts: how effective are the countermeasures? British Journal of Sports Medicine, 2001. 35(1), 8-19.

11. Delas S, Babin J, Kati, R. Effects of BiomotorStructur es on PerformanceofCompetitiveGymnasticsElements in Elementary School FemaleSixth-Graders. Originalscientificpaper, 2007. 4, 979-985.

12. Demirel N, Şirinkan A, Şirinkan ŞÖ. Yaz spor okulunda jimnastik eğitimi alan okulöncesi çağı öğrencilerinin Eurofit testleriyle fiziksel gelişimlerinin incelenmesi (Erzurum örneği). International Journal of SocialSciencesandEducationResearch, 2016. 2(2), 688-694.

13. Durukan H, Koyuncuoğlu K, Şentürk U. Okul Öncesi Çocuklarda Temel Cimnastik Programının Motor Gelişim Açısından İncelenmesi. CBÜ Beden Eğitimi ve Spor Bilimleri Dergisi, 2016. 11(2), 131-140.

14. FederationInternationale De Gymnastique [InternationalGymnastıcsFederation](2005). Code de Pointage-GymnastiqueArtistiqueMasculine [Code of Point-Male ArtisticGymnastics]. Moutier, SwitzerlandFig. 2005

15. https://www.yok.gov.tr/Documents/Kurumsal/egitim_ogreti m_dairesi/Yeni-Ogretmen-Yetistirme-Lisans-

Programlari/Beden_Egitimi_ve_Spor_Ogretmenligi_Lisans_P rogrami.pdf

16. Jemnı MF, Friemel W. Sands, Mikesky A. EvolutionDu Profil PhysiologiqueDesGymnastesDurantLes 40 DernieresAnnees. [Gymnasts' Physiological Profile EvolutionDuringTheLast 40 Years]. Can. J. Appl. Physiol. 2001. 26:442-456.

17. Kankal MB, 9-12 Yaş Grubu Aerobik Jimnastik Ve Ritmik Jimnastik Sporcularının Fiziksel, Fizyolojik Ve Performans Özelliklerinin Karşılaştırılması. T.C. Ankara Üniversitesi Sağlık Bilimleri Enstitüsü, Beden Eğitimi Ve Spor Anabilim Dalı Yüksek Lisans Tezi. ANKARA, 2008.

18. Kesilmiş İ. 4-6 Yaş Çocuklarda Cimnastik Antrenmanının Büyüme ve Biyomotor Yetiler Üzerine Etkisi. Yüksek Lisans Tezi. Mersin Üniversitesi, Eğitim Bilimleri Enstitüsü, Beden Eğitimi ve Spor ABD, Mersin. 2012.

19. Kılıç B, Yüce, A, Gümüşdağ H, Kata, A. Spor yaralanmaları üst ekstremite yaralanmaları kapsaminda omuz yaralanmaları ve tedavi yöntemleri. Uluslararası hakemli akademik spor sağlık ve tıp bilimleri dergisi, 12(4), 1-26.

20. Major, J. (1996). Strength Training Fundamentals in GymnasticsConditioningUniversity of Utah, 2014. 16, No. 8., 11,12 .

21. Özer Ö, Kılınç F. Elite athletes in individual and team strength, speed and flexibility to compare their performance. International J Human Sciences, 2012. 9(1): 360-371

22. Pınar S. Üst Seviyedeki Türk Cimnastikcilerinde Seri Sonrası Laktik Asit Miktarının Ölçülmesi ve Diğer Parametrelerle (seri süresi, yoğunluğu, puanı) Karşılaştırılması. Spor Bilim. 1991. 5: 16-19.

23. Savucu Y, Karata, M, Eskiyecek CG., Yücel AS, Karadağ M. 6-7 Yaş Gurubu Erkek Çocuklarda 12 Haftalık Temel Jimnastik Eğitiminin Fiziksel Uygunluklarına Etkisi. TurkishJournal of EducationalStudies, 2018. 5(3), 53-65.

24. Tatlıcı A, Çakmakçı E, Yılmaz S, \& Arslan F. Comparison of visual reaction values of elite deaf wrestlers and elite normally hearing wrestlers. 2018.

25. Tatlici A, Cakmakci O. The effects of acute dietary nitrate supplementation on anaerobic power of elite boxers. MEDICINA DELLO SPORT, 2019. 72(2), 225-233.

26. Sever O. Statik ve Dinamik Core Egzersiz Çalışmalarının Futbolcuların Sürat ve Çabukluk Performansına Etkisinin Karşılaştırılması. Gazi Üniversitesi Sağlık Bilimleri Enstitüsü. 
Beden Eğitimi ve Spor Anabilim Dalı. Doktora Tezi. Ankara, 2016.

27. Sands WA, Caine DJ, Borms J. ScientificAspects of Women'sGymnastics. Basel, Switzerland: Karger, 2002. pp. 128-161.

28. Şentürk T, Sezen M, Artistik Cimnastikte Yunus Takla Hareketinin Öne Salto Öğretimine Transferinin İncelenmesi, Dergi Park, Gazi Beden Eğitimi ve Spor Bilimleri Dergisi, 1999. Cilt 4, Say1 2, Sayfalar $23-30$

29. Tetik S, Koç MC, Atar Ö, Koç H. Basketbolcularda Statik Denge Performansı İle Oyun Değer Skalası Arasındaki İlişkinin İncelenmesi. Türkiye Kickboks Federasyonu Spor Bilimleri Dergisi, 2013. Volume: 6, Sayı:1,

30. Ünlü G, Tatlıcı A. Elit Güreşçilerde ProprioseptifNöromuskulerFasilitasyon (Pnf) Uygulamalarının Dinamik Denge Performansına Akut Etkileri. Sportif Bakış: Spor Ve Eğitim Bilimleri Dergisi, 2018. 57-63.

31. Vandorpe B, Vandendriessche J., Vaeyens R, Pion J, Lefevre J, Philippaerts $\mathrm{RL}$, Factorsdiscriminatinggymnastsbycompetitivelevel. Int. J. SportMed. 2011. 32, $591-597$.

32. Yüksel O, Akın S. TheEffects Of 8 WeeksCoreTraınıng On DynamicBalance Of Elite Level BadmintonPlayers. EuropeanJournal of Physical Education and SportScience, 2017. 